\title{
Synergistic Effect of Cinnamon Essential Oil (Cinnamomum burmannii) and Doxorubicin on T47D Cells Correlated with Apoptosis Induction
}

\author{
Etyk Yunita Anjarsari, Nita Kristiani, Yonika Arum Larasati, \\ Dyaningtyas Dewi P. Putri, Edy Meiyanto*
}

Cancer Chemoprevention Research Center Faculty of Pharmacy, Universitas Gadjah Mada, Yogyakarta, Indonesia

\begin{abstract}
Cinnamon (Cinnamomum burmannii) shows anticancer activity in several types of cancer cells. The aim of this study is to observe the cytotoxic activity of cinnamon essential oil (CEO) solely and its combination with doxorubicin, also the ability of the combination to induce apoptosis on T47D breast cancer cells. The CEO was prepared through distillation of dry cinnamon bark. Cytotoxic assay was performed by using MTT assay and apoptosis determination was done by using double staining with ethidium bromide and acridine orange. The result showed that CEO exhibited cytotoxic effect on T47D cells with IC 50 values of 75 $\mu \mathrm{g} / \mathrm{mL}$. Moreover, CEO showed synergist effect with doxorubicin. The lowest combination index $(\mathrm{Cl})$ with $\mathrm{Cl}$ values of 0,37 was obtained by combination of doxorubicin-CEO 37.5 $\mu \mathrm{g} / \mathrm{mL}-1.25 \mu \mathrm{M}$. Treatment with CEO solely and its combination with doxorubicin showed apoptosis induction on T47D cells. The results of this study indicate the potency of CEO to be developed as co-chemotherapeutic agent of doxorubicin on breast cancer.
\end{abstract}

Keywords: cinnamon essential oil, doxorubicin, T47D cells, combination cytotoxic

\section{INTRODUCTION}

Cancer is one of the major human diseases and causes considerable suffering and economic loss worldwide. Breast cancers show high incidence over the world and there are estimated over 200,000 new cases of breast cancer on American women (American Cancer Society, 2013). Selective eradication of cancer cells is an important goal for cancer chemotherapy in the $21^{\text {st }}$ century. Chemotherapeutic agent, such as doxorubicin, causes several side effect such as depression of immune system (Wattanapitayakul, et al., 2005) and resistance of cáncer cells (Smith, et al., 2006).

Combination of chemotherapy (cochemotherapy) is a strategy to make cancer therapy become more effective, safe, and suppress side effect of doxorubicin. Phytochemicals are potential to be developed as anticancer agent (Tyagi, et al., 2004) and several compounds could be found in cinnamon bark. The active component of cinnamon bark, cinnamaldehyde, performes antiproliferative activity in several cancer cells such as lung, renal, colon, CNS, melanoma, breast, leukemia, ovary, and prostate (Lee, et al., 1999). The aim of this study is to observe the synergistic effect of cinnamon essential oil (CEO) combined with doxorubicin in cytotoxic effect and apoptosis induction on T47D breast cancer cells. The results of this study can be a reference for further research of developing CEO as potential co-chemotherapeutic agent.

\section{MATERIALS AND METHODS}

\section{Cinnamon Essential Oil (CEO)}

Cinnamon bark was obtained from Boyolali, Central Java, Indonesia and determined in Pharmaceutical Biology Laboratory, Faculty of Pharmacy, UGM. The barks was dried and chopped, then placed in the sample flask.

*Corresponding author e-mail: meiyan_e@ugm.ac.id 
Aquadest was added to the water flask $( \pm 3 \mathrm{~L}$ ) and boiled until $100^{\circ} \mathrm{C}$. Steam was produced under the sample and condensed as distillate.

\section{Cell Culture}

T47D cells was obtained from Prof. Tatsuo Takeya (Nara Institute of Science and Technology, Japan) and cultured in Dulbecco's modified Eagle's medium (DMEM; Gibco) supplemented with $10 \%$ fetal bovine serum (FBS; Gibco) and 1\% v/v 10,000 units/mL penicillin- $10,000 \mu \mathrm{g} / \mathrm{ml}$ streptomycin (Gibco) at temperature $37^{\circ} \mathrm{C}$ and with a flow of $5 \% \mathrm{CO}_{2}$.

\section{Cytotoxic Assay}

T47D cells were seeded in 96-well plate with $1 \times 10^{4}$ cells/well and divided into control and treatment group. Final concentrations of CEO were 50, 100, 150, 200, 300, 400 and 500 $\mu \mathrm{g} / \mathrm{mL}$ while concentration of doxorubicin were $5,10,20,30,40$, and $50 \mu \mathrm{M}$. Concentration series of CEO and doxorubicin then diluted in culture medium up to the final concentrations. After $24 \mathrm{~h}$ incubation, culture medium was removed and cells were washed using PBS (Sigma). Five $\mathrm{mg} / \mathrm{mL}$ of MTT on PBS (Sigma) was diluted by DMEM (1:9) and $100 \mu \mathrm{L}$ of it was added into each well. After incubation for 3 hours, the reaction was stopped by Sodium Dodecyl Sulfate (SDS) $10 \%$ in HCL $0.01 \mathrm{~N}$. The plate then incubated for one night in room condition at dark place. To make sure the formazan dissolve, the plate was shaken for 10 minutes and the absorbance was measured using ELISA reader at wave length of $595 \mathrm{~nm}$.

\section{Apoptosis Induction}

Cover slips were placed on 24 wells tissue culture plate. T47D cells were seeded at $5 \times 10^{4}$ cells/well. After 24 hours of incubation, cells were treated with CEO, doxorubicin, and combination of CEO and doxorubicin. After 24 $\mathrm{h}$ of these treatments, cells were washed. Cover slips were taken and put on the object glass and added by $10 \mu \mathrm{L} 1 \mathrm{X}$ working solution ethidium bromide-acridin orange (Kasibhatla, et al., 2006). The treated cells then observed under fluorescent microscope.

\section{Data Analysis}

Single Cytotoxicity Assay. Linear regression between concentration and \% cell viability giving the equation $\mathrm{y}=\mathrm{Bx}+\mathrm{A}$ were used to calculate $\mathrm{IC}_{50}$ value, that is the concentration inhibiting $50 \%$ cell proliferation.

Combinational Cytotoxicity Assay. Combinational treatment was evaluated by calculating Combination Index (CI) value (Reynolds and Maurer, 2005), which has the formula as follows.

$$
\mathrm{CI}=\mathrm{D} 1 / \mathrm{D} \mathrm{x} 1+\mathrm{D} 2 / \mathrm{Dx} 2
$$

D1 and D2 represent concentrations used in combinational treatment, while Dx1 and Dx2 are single treatment concentration giving the same response as D1 and D2, respectively. CI value acquired will allow the evaluation of CEO's potency in combinatorial treatment with doxorubicin on T47D cells. Interpretation was done based on classification listed in Table 1 .

Table I. Interpretation of $\mathrm{Cl}$ value representing potency of combinational application

\begin{tabular}{llll}
\hline $\mathbf{C l}$ & Interpretation & $\mathbf{C l}$ & Interpretation \\
\hline$<0.1$ & Very strong synergist & $0.9-1.1$ & Closely additive \\
$0.1-0.3$ & Strongly synergist & $1.1-1.45$ & Middle antagonist \\
$0.3-0.7$ & Synergist & $1.45-3.3$ & Antagonist \\
$0.7-0.9$ & Middle synergist & $>3.3$ & Strongly antagonist \\
\hline
\end{tabular}




\section{RESULTS AND DISCUSSION}

\section{Effect of Cinnamon Essential Oil (CEO) and Doxorubicin on T47D Cells Growth}

CEO with dose range of $50-400 \mu \mathrm{g} / \mathrm{mL}$ inhibited cell viability of T47D with $\mathrm{IC}_{50}$ value of $75 \mu \mathrm{g} / \mathrm{mL}$. Along with the increase of CEO dose, cell viability was decrease (Fig.1A). CEO caused morphological changes in the cells (Fig.1C-E) while there were no morphological changes in control cells (Fig.1B).

\section{Effect of Cinnamon Essential Oil (CEO) Combined with Doxorubicin on T47D Cells Growth}

Combination assay was done by combining 1/2,1/4, 1/8,1/20 $\mathrm{IC}_{50}$ of CEO and doxorubicin. The $\mathrm{IC}_{50}$ of CEO was $75 \mu \mathrm{g} / \mathrm{mL}$ and $\mathrm{IC}_{50}$ of doxorubicin from the previous research was $10 \mu \mathrm{M}$ (unpublished data). Thus, combination dose for CEO were 37.5; 18.75;
9.375; $3.75 \mu \mathrm{g} / \mathrm{mL}$ and doxorubicin were $5 ; 2.5$; 1.25; dan $0.5 \mu \mathrm{M}$. Combination of CEO and doxorubicin decreased cell viability compared to doxorubicin alone. Combination index (CI) was calculated to evaluate the synergistic effect of the combination.

Results showed nine combinations performed synergistic effects, with the CI values of less than 0.9 (Reynolds and Maurer, 2005). The smallest CI showed by combination of $37.5 \mu \mathrm{g} / \mathrm{mL}$ CEO and $1.25 \mu \mathrm{M}$ doxorubicin (Table 2).

Treatment with combination of CEO $37.5 \mu \mathrm{g} / \mathrm{mL}$ and doxorubicin $1.25 \mu \mathrm{M}$ reduced cell viability significantly different with single treatment of each agent. While combination treatment with lower concentration of CEO $(9.375 \mu \mathrm{g} / \mathrm{mL})$ and doxorubicin did not reduce cell viability significantly compound to the doxorubicin solely (Fig. 2).

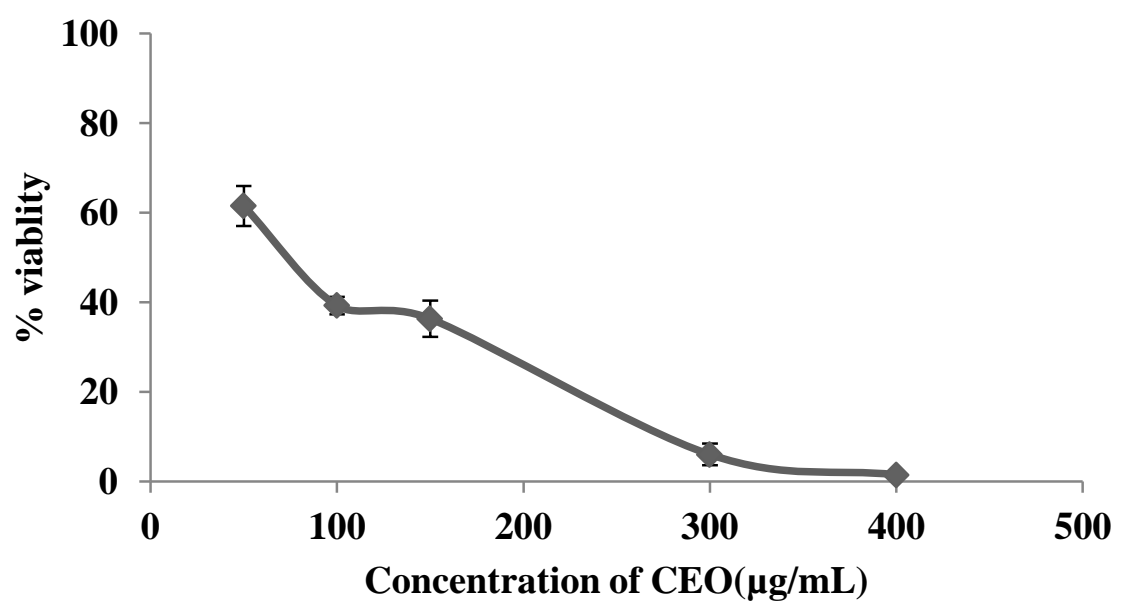

(A)

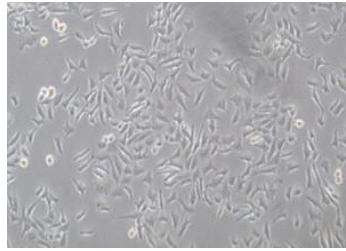

(B)

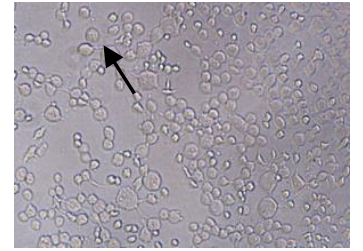

(C)

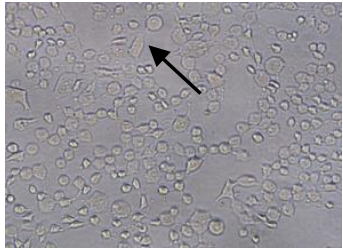

(D)

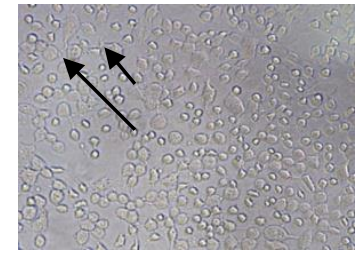

(E)

Figure I. Effect of cinnamon essential oil (CEO) and doxorubicin on T47D cells growth. (A) Graphic between CEO dose and T47D cells viability. CEO cytotoxicity expressed by percent cell viability is shown as the mean $+\mathrm{SE}$ of 3 experiments. IC 50 values obtained from the calculation of linear regression of concentration vs $\%$ viable cells with $p<0.05$. CEO showed cytotoxicy effect on T47D cells in dose dependent manner; (B) Morphology of cells without treatment; (C) treatment of CEO $50 \mu \mathrm{g} / \mathrm{mL}$; (D) treatment of CEO I50 $\mu \mathrm{g} / \mathrm{mL}$; $(E)$ treatment of CEO $300 \mu \mathrm{g} / \mathrm{mL}$. Arrows $(\rightarrow)$ indicates cells undergoing morphological changes. 
Table 2. Combination Index combination of CEO and doxorubicin

\begin{tabular}{cllll}
\hline CEO $(\mu \mathrm{g} / \mathrm{mL})$ & \multicolumn{4}{c}{ Doxorubicin $(\boldsymbol{\mu M})$} \\
\cline { 2 - 5 } & 0.5 & 1.25 & 2.5 & 5 \\
\hline 3.75 & 0.52 & 0.64 & 0.57 & 0.50 \\
9.375 & 1.59 & 0.68 & 0.60 & 2.68 \\
18.75 & 2.81 & 1.56 & 1.32 & 1.17 \\
37.5 & 4.90 & 0.37 & 0.42 & 0.53 \\
\hline
\end{tabular}

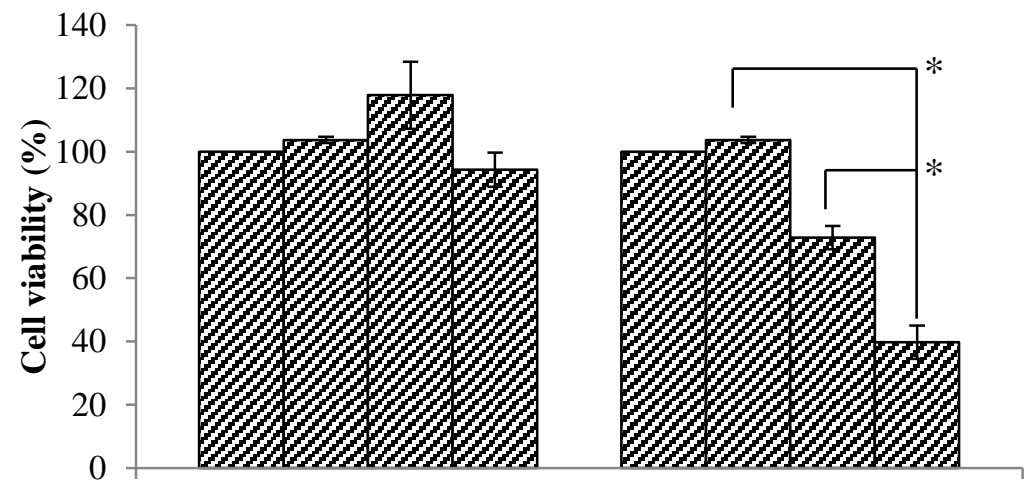

\begin{tabular}{lccccccccc}
\hline Dox $1.25 \mu \mathrm{M}$ & - & + & - & + & - & + & - & + \\
\hline DKM $9.375 \mu \mathrm{g} / \mathrm{mL}$ & - & - & + & + & & - & - & - & - \\
\hline DKM $37.5 \mu \mathrm{g} / \mathrm{mL}$ & - & - & - & - & & - & - & + & + \\
\hline
\end{tabular}

Figure 2. Effect of CEO in combination with doxorubicin on T47D cell viability. Cytotoxic assay was done under MTT reaction as described in the methods. Graph represented from the means of 3 independent experiments and analyzed with ANOVA one way with $p<0.05$.

\section{Effect of CEO and Doxorubicin on Apoptosis Induction}

Double staining using ethidium bromide and acridin orange was used to observe the induction of apoptosis. Single treatment of CEO $37.5 \mu \mathrm{g} / \mathrm{mL}$ and doxorubicin $5 \mu \mathrm{M}$ induced apoptosis of T47D cells. Apoptotic induction was indicated by orange fluorescent in the nucleus (Fig.3, red arrows). The result showed that combination treatment of CEO and doxorubin increased the number of cells containing red/orange fluorescent. These data indicated that the combination of CEO and doxorubicin increased the incidence of apoptosis. 


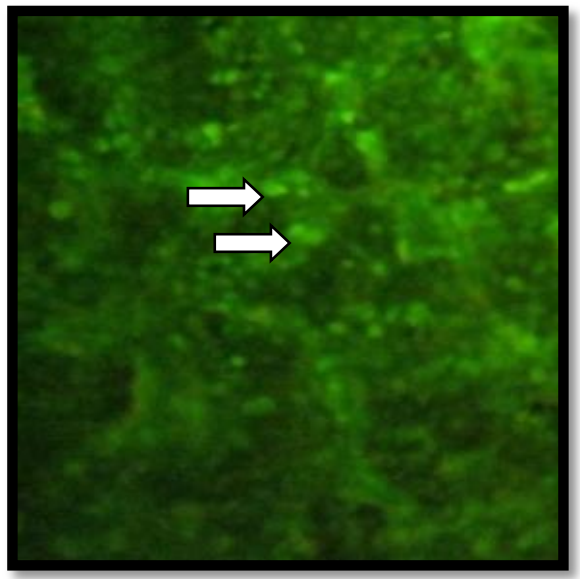

(A)

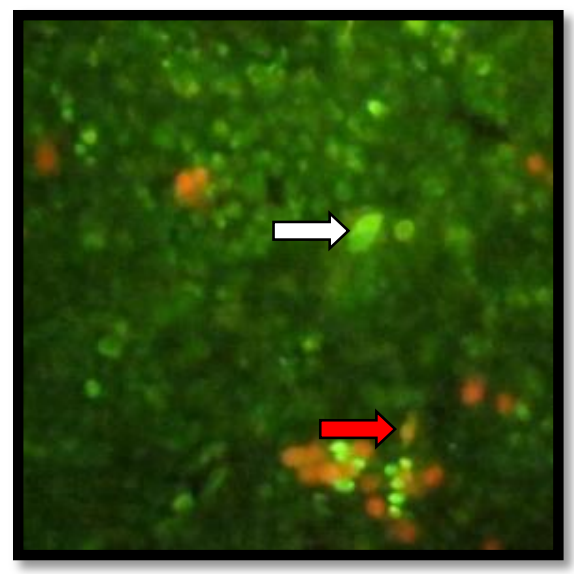

(C)

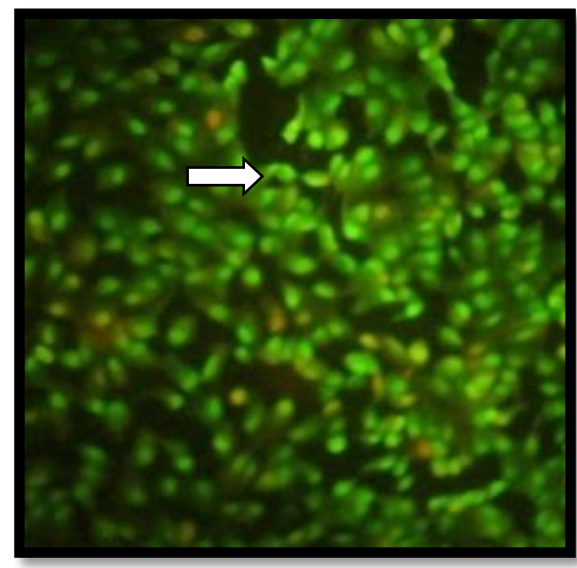

(B)

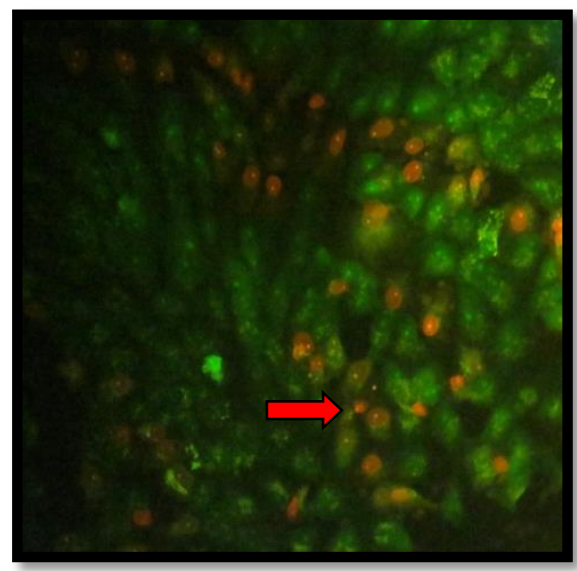

(D)

Figure 3.Effect of CEO and doxorubicin on apoptosis. (A) Morphology of cells without treatment; (B) treatment of doxorubicin $5 \mu \mathrm{M}$; (C) treatment of CEO $37.5 \mu \mathrm{g} / \mathrm{mL}$; (D) treatment combination of CEO $37.5 \mu \mathrm{g} / \mathrm{mL}$ and doxorubicin $5 \mu \mathrm{M}$. Arrows $(\Longrightarrow$ ) viable cells that has green fluorescent, arrows $(\vec{\square})$ apoptosis cells that has orange fluorescent.

CEO showed cytotoxic effect on breast cancer T47D cells. CEO inhibited T47D cells growth with IC50 value of $75 \mu \mathrm{g} / \mathrm{mL}$. According to Ueda, et al. (2000), extract with IC50 below $100 \mu \mathrm{g} / \mathrm{mL}$ is potential to be developed as anticancer agent. CEO also increased cytotoxic activity of doxorubicin on T47D cells, indicated by cell viability decrease compared to doxorubicin treatment solely. This mean that when combined with CEO, doxorubicin dose could be decreased but gave the same effect on cancer cells.

Synergistic effect of combination of CEO and doxorubicin could be done through several mechanisms, such as apoptosis induction and/or cell cycle modulation. In this study, double staining method was done to confirmed apoptosis induction by CEO and doxorubicin. From this study, combination of CEO $(37.5 \mu \mathrm{g} / \mathrm{mL})$ and doxorubicin $(5 \mu \mathrm{M})$ increased apoptosis incidence compared to each compound solely.

Doxorubicin usually need p53 to induce apoptosis (Drummond, 2007), while T47D has mutant p53. Thus, apoptosis induction on T47D is probably through p53-independent pathway. Doxorubicin also has been known to activate $\mathrm{NF} \kappa \mathrm{B}$. $\mathrm{NF} \kappa \mathrm{B}$ activation leading to expression 
of anti-apoptotic protein, such as Bcl-xL (Pahl, 1999). On the other hand, aqueous extract of cinnamon has been known to inhibit $\mathrm{NF} \kappa \mathrm{B}$ activation (Kwon, et al., 2010). By $\mathrm{NF} \kappa \mathrm{B}$ inhibition, expression of anti-apoptotic protein could be inhibited. Nevertheless, further research has to be done to observe effect of $\mathrm{CEO}$ and doxorubicin on expression of protein related with apoptotic pathway.

Previous study showed that cinnamaldehyde, major compound in cinnamon, induced apoptosis through mitochondrial permeability transition (MPT) (Ka, et al., 2003). Increase of mitochondrial membran permeability caused cytochrome c excess, then activate caspase 3 and leading to apoptosis (Mizutani, et al., 2005).

But, cytotoxic activity in CEO seems likely not only caused by cinnamaldehyde. Singh, et al. (2007) reported that aqueous cinnamon extract (ACE) showed stronger cytotoxic effect compared to cinnamaldehyde alone. There are some polyphenol compounds that might has synergistic effect with cinnamaldehyde. Thus, distillate standardization is needed to be done as well as to know more active compound in the CEO.

\section{ACKNOWLEDGEMENT}

Our thanks are to Cancer Chemoprevention Research Center (CCRC), which has funded this research.

\section{REFERENCES}

American American Cancer Society, Breast Cancer Facts \& Figures 20/3-20/4, Atlanta: American Cancer Society, Inc. 2013.

Drummond, C., 2007, The Mechanism of Antitumour Activity of the DNA Binding Agent SN 28049, Thesis, University of Auckland, New Zealand.

Ka, H., Park, H.J., Jung, H.J., Choi, J.W., Cho, K.S., Ha, J. and Lee, K.T., 2003, Cinnamaldehyde Induces Apoptosis by ROS-mediated Mitochondrial Permeability Transition in Human Promyelocytic Leukemia HL-60 cells, Cancer Lett., I 96(2), I43-I52.

Kasibhatla, S., Amarate-Mendes, G.P., Finucane, D., Bruner, T., Bossy-Wetzel, E. and Green, D.R., 2006, Acridine
Orange/Ethidium Bromide (AO/EB) Staining to Detect Apoptosis, CHS Protoc., 2006(3).

Kwon, H.K., Hwang, J.S., So, J.S., Lee, C.G., Sahoo, A., Ryu, J.H., et al., 2010, Cinnamon Extract Induces Tumor Cell Death Through Inhibition of NFkB and API, BMC Cancer, I O(I), 392.

Lee, C.W., Hong, D.H., Han, S.B., Park, S.E., Kim, H.K., Kwon, B.M., et al., 1999, Inhibition of Human Tumor Growth by 2'- Hydroxyl- and 2'- Benzoyloxycinnamaldehydes, Planta Med., 65(3), 263-266.

Mizutani, H., Oikawa, S.T., Hiraku, Y., Kojima, M. and Kawanishi, S., 2005, Mechanism of Apoptosis Induced by Doxorubicin Through the Generation of Hydrogen Peroxide, Life Sci., 76(I3), I439-I453.

Pahl, H.L., 1999, Activators and Target Genes of Rel/NFkB Transcription Factors, Oncogene, I 8(49), 6853-6866.

Reynolds, C.P. and Maurer, B.J., 2005, Evaluating Response to Antineoplastic Drug Combinations in Tissue Culture Models, Methods in Molecular Medicine, Methods Mol. Med., I I0, 173-183.

Singh, G., Maurya, S.S., Delampasona, M.P. and Catalan, C.A.N., 2007, A Comparison of Chemical, Antioxidant and Antimicrobal Studies of Cinnamon Leaf and Bark Volatile Oils, Oleoresins and Their Constituents, Food Chem. Toxicol., 45(9), I650-I66I.

Smith, L., Watson, M.B., O'Kane, S.L., Drew, P.J., Lind, M.J. and Cawkwell, L., 2006, The Analysis of Doxorubicin Resistance In Human Breast Cancer Cells Using Antibody Microarrays, Mol. Cancer Ther., 5(8), 2I I5-2I 20.

Tyagi, A.K., Agarwal, C., Chan, D.C.F. and Agarwal, R., 2004, Synergistic Anti Cancer Effects of Silibinin with Conventional Cytotoxic Agents Doxorubicin, Cisplatin, and Carboplatin Against Human Breast Carcinoma MCF-7 and MDA-MB468 Cells, Oncol. Rep., I I (2), 493-499.

Ueda, J.Y., Tezuka, Y., Banskota, A.H., Tran, Q.L., Tran, Q.K., Harimaya, Y., et al., 2002, Antiproliferative Activity of Vietnamese Medicinal Plants, Biol. Pharm. Bull, 25(6), 753-760. 
Wattanapitayakul, S.K., Chularojmontri, L., Herunsalee, A., Charuchongkolwongse, S., Niumsakul, S. and Bauer, J.A., 2005, Screening of
Antioxidants from Medicinal Plants for Cardioprotective Effect Against Doxorubicin Toxicity, Basic Clin. Pharmacol. Toxicol, 96(I), 80-87. 